\title{
NOTES
}

\section{FIRST EVIDENCE OF BREEDING OF THE RED-NECKED GREBE IN CALIFORNIA}

KENNETH P. ABLE, Bob's Creek Ranch, 535-000 Little Valley Road, McArthur, California 96056; kennethpable@gmail.com

On 13 September 2019, I observed an adult Red-necked Grebe (Podiceps grisegena) accompanying two large young in juvenal plumage (Figure 1) near the boat-launch site on Big Lake, $\sim 6 \mathrm{~km}$ north of McArthur, Shasta County, California. Covering $\sim 3 \mathrm{~km}^{2}$, Big Lake is a relatively shallow ( $\sim 4 \mathrm{~m}$ deep) spring-fed lake at an elevation of $1008 \mathrm{~m}$. With other connected water bodies (Horr Pond, Tule, Little Tule, and Fall rivers), it is part of a large hydroelectric project constructed in the early decades of the $20^{\text {th }}$ century. The lake and several small islands are surrounded by a dense band of emergent aquatic vegetation, primarily tule (Schoenoplectus acutus). Pied-billed (Podilymbus podiceps), Eared (Podiceps nigricollis), Western (Aechmophorus occidentalis), and a few Clark's (A. clarkii) Grebes nest on the lake.

I observed the Red-necked Grebes from 14:20 to 15:20 PDT. The juveniles spent a majority of their time hidden in the shoreline tules. During this time, the adult patrolled in open water nearby. The juveniles emerged from the tules occasionally and consorted with the adult. When in the same field of observation with the adult, the juveniles appeared slightly smaller. Both juveniles dove numerous times during these forays in the open, but I did not see them catch anything. The adult was diving regularly during my observation, and it surfaced with prey on several occasions.

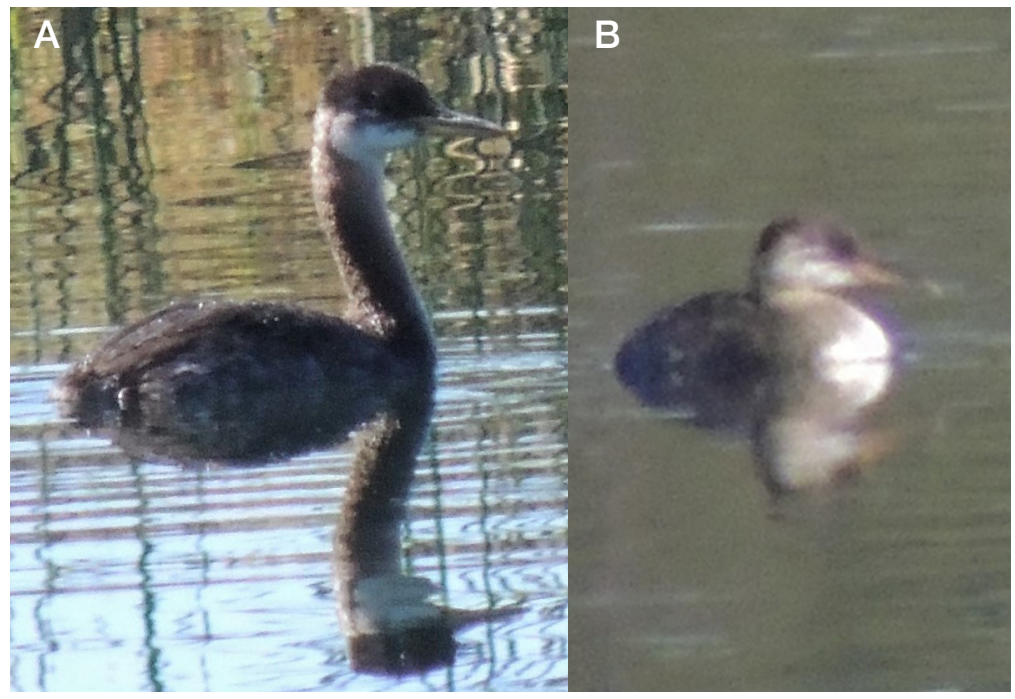

FIGURE 1. Adult (A) and one of two fledgling (B) Red-necked Grebes at Big Lake, near McArthur, Shasta County, California, 13 September 2019.

Photos by Kenneth P. Able 


\section{NOTES}

The adult did not feed the young birds while I was watching them, nor did they approach the adult and beg.

In the northwestern United States, the Red-necked Grebe breeds in northeastern Washington, northern Idaho, and northwestern Montana (AOU 1998, Dunn and Alderfer 2017). An isolated population at Rocky Point on Upper Klamath Lake, Klamath County, Oregon ( 165 km north-northwest of Big Lake), comprising from five to 20 birds, represented the only consistent breeding locality in that state known to Marshall et al. (2003). This population has declined, and there has been no documentation of nesting in recent years (Kevin Spencer pers. comm.). Occasional single adult Red-necked Grebes are reported in summer from inland Oregon and inland northern California, rarely in June and July, more frequently during August (www.eBird.org).

I do not know if the juvenile grebes were still flightless when I observed them. This raises the question whether the birds did not breed on Big Lake (or immediately connected bodies of water), but flew there from a distant nesting site. Given the Red-necked Grebe's breeding behavior, this seems unlikely. Young Red-necked Grebes begin to make exploratory dives by 2 weeks of age, are diving and feeding at about 4 weeks, but depend on parents for food for 6-8 weeks. They are able to fly by 7-9 weeks of age (De Smet 1983, Stout and Nuechterlein 1999). Departure from nesting lakes is staggered. One adult typically leaves 1-3 weeks prior to its mate, and both parents depart before their young, which disperse independently several days apart (De Smet 1983). An adult attending two juveniles indicates probable nesting locally, representing the first record of the Red-necked Grebe breeding in California.

Thanks to Kevin Spencer for providing current information on the grebes at Klamath Lake, Joseph R. Jehl for enlightenment about the parental behavior of grebes, and Jon L. Dunn, Kathy Molina, and Kimball Garrett for comments on the manuscript.

\section{LITERATURE CITED}

American Ornithologists' Union. 1998. Check-list of North American Birds, $7^{\text {th }}$ ed. Am. Ornithol. Union, Washington, D.C.

De Smet, K. D. 1983. Breeding ecology and productivity of Red-necked Grebes in Turtle Mountain Provincial Park, Manitoba. Master's thesis, Univ. of North Dakota, Grand Forks; https://commons.und.edu/theses/1162.

Dunn, J. L., and Alderfer, J. 2017. A Field Guide to the Birds of North America, $7^{\text {th }}$ ed. Natl. Geogr. Soc., Washington, D.C.

Marshall, D. B., Hunter, M. G., and Contreras, A. B. 2003. Birds of Oregon: A General Reference. Ore. State Univ., Corvallis.

Stout, B. E., and Nuechterlein, G.L. 1999. Red-necked Grebe (Podiceps grisegena), in The Birds of North America (A. F. Poole and F. B. Gill, eds.), no. 165. Acad. Nat. Sci., Philadelphia; doi.org/10.2173/bna/465. 